\title{
Antibodies anti-trypanosomatides in domestic cats in Paraná: who is at highest risk of infection?
}

Anticorpos anti-tripanossomatídeos em gatos domésticos no Paraná: quem está em maior risco de infecção?

\author{
Andressa Maria Rorato Nascimento de Matos ${ }^{1 *}$; Eloiza Teles Caldart ${ }^{1}$; Fernanda Pinto Ferreira ${ }^{1}$; \\ Keila Clarine Monteiro ${ }^{1}$; Marielen de Souza ${ }^{1}$; Déborah Thais Silva Cepelo Brunieri ${ }^{1}$; Carmen Lúcia Scortecci Hilst ${ }^{2}$; \\ Nilva Maria Freres Mascarenhas ${ }^{2}$; Regina Mitsuka-Breganó ${ }^{1}$; Roberta Lemos Freire ${ }^{1}$; Italmar Teodorico Navarro ${ }^{1}$ \\ ${ }^{1}$ Laboratório de Zoonoses e Saúde Pública, Departamento de Medicina Veterinária Preventiva, Universidade Estadual de Londrina - \\ UEL, Londrina, PR, Brasil \\ ${ }^{2}$ Departamento de Clínicas Veterinárias, Universidade Estadual de Londrina - UEL, Londrina, PR, Brasil
}

Received October 26, 2017

Accepted April 05, 2018

\begin{abstract}
The aim of this study were to detect antibodies anti-Leishmania spp. and anti-Trypanosoma cruzi in two different populations of domestic cats (Felis catus domesticus) from North Paraná referred for surgical castration and to determine which characteristics of the animals studied may be associated with seropositivity. Serum samples from 679 cats were analyzed using enzyme-linked immunosorbent assay (ELISA) and indirect immunofluorescence antibody test (IFAT) in series. Associations between age, sex, race, year of care and animal group were verified using the simple logistic regression. Percentage of $8.5 \%$ (58/679) of cats were positive for Leishmania spp. and 7.6\% (51/673) for T. cruzi by the tests ELISA and IFAT. Animals collected by non-governmental animal protection organizations presented more seropositivity for Leishmania spp. ( $\mathrm{p}<0.0001)$. Results shown that Leishmania spp. and T. cruzi are present in domestic cats in the northern part of the state of Paraná, as well as, owners of non-governmental animal protection organizations may be more exposed to leishmaniasis when compared to other animal owners evaluated in the present study.
\end{abstract}

Keywords: Domestic feline, American cutaneous leishmaniasis, Trypanosoma cruzi, zoonosis, seroepidemiology, prevalence.

\section{Resumo}

O objetivo desse estudo foi detectar a presença de anticorpos IgG anti-Leishmania spp. e anti-Trypanosoma cruzi em duas populaçóes de gatos domésticos (Felis catus domesticus) do Norte do Paraná encaminhados para castraçáo cirúrgica e determinar quais as características dos animais estudados que podem estar associadas à soropositividade. Amostras de soro de 679 gatos foram analisadas utilizando-se os testes imunoenzimático (ELISA) e a reação de imunofluorescência indireta (RIFI), em série. Associações entre idade, sexo, raça, ano de atendimento e grupo animal foram verificadas usando regressão logística simples. Um percentual de 8,5\% (58/679) dos gatos apresentou positividade para Leishmania spp. e 7,6\% (51/673) para T. cruzi pelos testes ELISA e RIFI. Gatos mantidos em organizaçôes não governamentais de proteçâo animal apresentaram maior sororeatividade para Leishmania spp. $(\mathrm{p}<0.0001)$. As sorologias reativas para Leishmania spp. e Trypanosoma cruzi mostram que esses agentes estâo presentes em gatos domésticos na parte norte do estado do Paraná, bem como, os proprietários de organizaçôes não governamentais de proteção animal podem estar mais expostos à leishmaniose quando comparados com outros proprietários de animais avaliados no presente estudo.

Palavras-chave: Felino doméstico, leishmaniose tegumentar americana, Trypanosoma cruzi, zoonoses, seroepidemiologia, prevalência.

Leishmania parasites can infect humans and numerous species of mammals which contract the disease through bites by Lutzomyia sand flies (GRAMICCIA, 2011; BRASIL, 2017). In urban areas, the

${ }^{*}$ Corresponding author: Andressa Maria Rorato Nascimento de Matos. Laboratório de Zoonoses e Saúde Pública, Departamento de Medicina Veterinária Preventiva, Universidade Estadual de Londrina - UEL, Rodovia Celso Garcia Cid, 445, Km 380, CEP 86057-970, Londrina, PR, Brasil. e-mail: andressarorato@gmail.com domestic dog is the main reservoir of Leishmania (L.) infantum (syn. chagasi), the etiological agent of visceral leishmaniasis (VL) in the Americas (BRASIL, 2014), while seven species act as etiological agents of american cutaneous leishmaniasis (ACL), including $L$. $(V$.) braziliensis and $L$. (L.) amazonensis (BRASIL, 2017). Both of these ACL parasites have been detected in dogs and humans in the state of Paraná (SILVEIRA et al., 1990, 1999; THOMAZ-SOCCOL, et al., 2009; HOFFMANN, et al., 2012). 
The increase in the number of registered cases of domestic felines infected with Leishmania suggests that this animal species may play an important role in the epidemiology of the disease (MANCIANTI, 2004). The first report of natural infection by L. (L.) infantum in cats in the Americas occurred in 2000 in Cotia, São Paulo state (SAVANI et al., 2004). Posteriorly, Brazilian studies reported the isolation of three Leishmania species in domestic felines: L. (V.) braziliensis, (SCHUBACH et al., 2004), L. (L.) amazonensis (SOUZA et al., 2005) and L. (L) infantum (VIDES et al., 2011). The domestic feline may harbor several Leishmania species without clinical signs, which, according to some authors, is due to natural resistance to infection (KIRKPATRICK et al., 1984); however, infection may be symptomatic when it co-occurs with immunosuppressive diseases (SOBRINHO et al., 2012).

Another important zoonosis found in 100 species of domestic and wild animals is caused by the flagellate protozoan Trypanosoma cruzi (Trypanosomatidae) and is called American trypanosomiasis or Chagas disease, which is considered by the WHO as an important and formerly neglected disease (WHO, 2013). The distribution of T. cruzi is primarily in the Americas due to the presence of the triatomine vector (Reduviidae) on this continent (WHO, 2015).

The role of felines in the maintenance of important pathologies such as leishmaniasis and trypanosomiasis has not been fully elucidated. However, data from this study corroborate the importance of health surveillance of felines in both endemic and non-endemic areas. Da Silva et al. (2008) suggested that the common habits of domestic cats may favor infection by different species of Leishmania, including hunting at night, having territories that extend up to $1.5 \mathrm{~km}$ away from the residence, and ability to co-inhabit urban and wild environments. These factors validate the importance of felines in the epidemiology of leishmaniasis (MAIA \& CAMPINO, 2011).

The aim of this study were to detect antibodies anti-Leishmania spp. and anti-Trypanosoma cruzi in two different populations of domestic cats (Felis catus domesticus) from North Parana referred for surgical castration and to determine which characteristics of the animals studied may be associated with seropositivity.

Between 2004 and 2014, 679 serum samples were collected from cats attended by birth control programs of the Veterinary Hospital (VH) at the Universidade Estadual de Londrina, state of Paraná, Brazil. Animals were collected from the Londrina

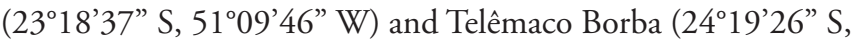
$\left.50^{\circ} 36^{\prime} 56^{\prime \prime} \mathrm{W}\right)$ municipalities, which are located in the northern and midwestern regions of Paraná, respectively.

The collection of serological samples from felines was carried out under the approval of the Committee for Ethics in the Use of Animals ( ${ }^{\circ}$ 60/08). The animals were divided into two groups: 414 from different neighborhoods of Londrina, referring to $\mathrm{VH}$ by their owners for surgical castration by the Birth Control Project (BCP), from 2004 to 2013; and 265 from Castration Campaign Project (CCP) of animals from non-governmental animal protection organizations of the cities of Londrina $(n=201)$ and Telêmaco Borba $(n=64)$, occurred in 2014 .

The serological enzyme-linked immunosorbent assay (ELISA) was adapted from Szargiki et al. (2009) to detect the presence of anti-Leishmania spp. and anti-T. cruzi IgG antibodies. The cut-off for each plate was obtained from the means of the negative sera readings plus three standard deviations. After the calculations made per plate, the overall cut-off was estimated using the receiver operating characteristic curve (ROC curve) by the MedCalc Statistical Software 13.2.0 (SCHOONJANS et al., 1995).

Indirect immunofluorescence antibody test (IFAT) was performed as described by Oliveira et al. (2008) using promastigote forms of L. amazonensis and T. cruzi epimastigotes as antigens. The slides were read on an epifluorescence microscope (DMLB Leica ${ }^{\circledR}$, Wetzlar, Germany). Samples with titers greater than or equal to 40 were considered positive for Leishmania spp., and titers greater than or equal to 20 were considered positive for T. cruzi.

The Epi Info program 7.1.5.2 (CDC, Atlanta, USA) was used to tabulate the variables age, sex, breed, animal group (BCP and $\mathrm{CCP}$ ), year of surgical service and tests results. For statistical analysis were considered only the animals reactive in the two serological tests (ELISA and IFAT), for Leishmania spp. or for T. cruzi. The statistical significance of the variables was analyzed using the program R 3.3.2 (R CORE TEAM, 2016) by simple logistic regression considering a significance level of $5 \%$. The association measure was obtained by the odds ratio (OR) calculation with a 95\% confidence interval (CI).

Among the cats attended by the birth control programs at the Londrina State University, 48.0\% (326/679) were female and $43.9 \%$ (298/679) were male, and for $8.1 \%(55 / 679)$ no information about sex was obtained. Regarding the age groups, $28.0 \%(190 / 679)$ were younger than one year of age, $25.5 \%$ (173/679) were aged between one and eight years, $0.1 \%(1 / 679)$ were older than eight years and we were unable to determined age in 46.4\% (315/679). Regarding breed, 3.2\% (22/679) of the cats had a defined breed, $88.4 \%$ (600/679) had no defined breed and we had no information for 8.4\% (57/679).

For the anti-Leishmania spp. antibody tests, 15.8\% (107/679) and 43.4\% (295/679) seropositivities were observed by IFAT and ELISA, respectively, and anti-T. cruzi antibodies were detected in 30.8\% (207/673) by IFAT and 23.6\% (159/673) by ELISA. Considering only the samples that were positive in both techniques performed, 8.5\% (58/679) of the animals were reactive for Leishmania spp. and 7.6\% (51/673) for T. cruzi. Table 1 shows the seropositivity in both serological tests (IFAT; ELISA; IFAT and ELISA) for Leishmania spp. and T. cruzi. Of the animals that were seroreactive by IFAT for both pathogens, nine presented equal titers for both protozoa, 47 showed higher titers for Leishmania spp. and only one showed higher titers for T. cruzi. Of the four seroreactive animals in both IFAT and ELISA for both protozoa, three presented titers of 40 for Leishmania spp. and 20 for T. cruzi and one had titers of 160 and 40, respectively.

Table 1. Number (n) and percentage (\%) of reactive domestic cats for Leishmania spp. and Trypanosoma cruzi in IFAT and ELISA serological tests.

\begin{tabular}{cccc}
\hline \multicolumn{1}{c}{ Parasites } & $\begin{array}{c}\text { IFAT } \\
\mathbf{n}(\%)\end{array}$ & $\begin{array}{c}\text { ELISA } \\
\mathbf{n}(\%)\end{array}$ & $\begin{array}{c}\text { IFAT/ELISA } \\
\mathbf{n}(\%)\end{array}$ \\
\hline $\begin{array}{l}\text { Leishmania spp. and } \\
\text { Trypanosoma cruzi }\end{array}$ & $57(8.39)$ & $78(11.48)$ & $4(0.58)$ \\
\hline
\end{tabular}

Source: The authors (2017). 
When analyzing the year of collection, it was verified that 2014 presented a larger number of animals with sororeactivity for Leishmania spp. than the other years of collection ( $\mathrm{p}<0.0001)$, and regarding T. cruzi, 2011 presented a larger number of animals with serum that reacted positively than the other years, except 2012 ( $p=0.0251$ ) (Figure 1). Furthermore, it was verified that the group BCP presented fewer animals with infection suspect by Leishmania spp. than the CCP group (non-governmental animal protection organizations) (Table 2 ). No statistically significant differences were found in the variables age, sex and breed for either Leishmania spp. or T. cruzi.

The region of the present study is endemic for human ACL and presented $15.8 \%$ and $43.4 \%$ positivity of feline samples by IFAT and ELISA, respectively. Following the same criteria adopted by the Ministry of Health for dogs, 8.5\% of cats were confirmed with leishmaniasis. Many of the seroprevalence studies for Leishmania spp. in cats have been carried out in endemic areas, mainly for VL (VIDES et al., 2011; ALVES-MARTIN, 2013; CARDIA et al., 2013; BRAGA et al., 2014). It is noteworthy that in Brazil, there are few records of anti-Leishmania spp. IgG antibodies in cats, the prevalence is generally low, and there are no records of studies demonstrating the seroprevalence behavior over the years.

Figure 1 shows that the feline seroprevalence values for Leishmania spp. of the present study were low or that infection was absent until the year 2013, whereas in 2014 there was a significant increase. Silveira et al. (2015) described three hypotheses for the

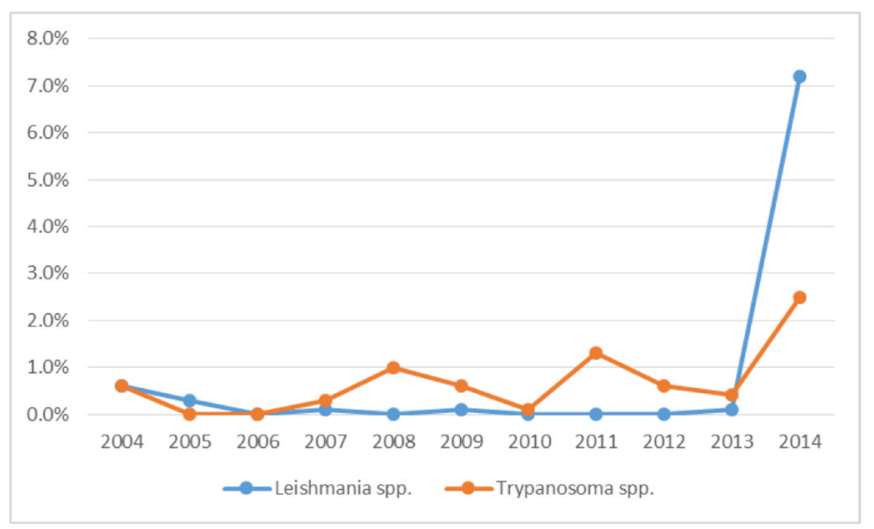

Figure 1. Percentage of seroreactive cats with Leishmania spp. and Trypanosoma cruzi as confirmed by ELISA and IFAT per year of collection. Source: The authors, 2017.

Table 2. Number (n), total of cats (Total), and percentage (\%) of reactive samples for Leishmania spp. in both serological tests, and factor associated with cats attended by the Birth Control programs of the Veterinary Hospital, from 2004 to 2014.

\begin{tabular}{lllc}
\hline Leishmania spp. & n/Total (\%) & p-Value & OR (IC 95\%) \\
\hline BCP (2004-2013) & $10 / 414(2.4)$ & $<0.0001$ & 1.00 \\
CCP - Londrina & $28 / 201(13.9)$ & & $6.53(3.10-13.75)$ \\
(2014) & & & \\
CCP - Telêmaco & $20 / 64(31.2)$ & & $18.36(8.73-38.63)$ \\
Borba (2014) & & & \\
\hline
\end{tabular}

BCP-Birth Control Programs; CCP-Castration Campaign Project. Source: The authors (2017). occurrence of higher seropositivity of Leishmania spp. in felines: the increase of active research in these hosts, the improvement of diagnostic techniques and an increased prevalence of leishmaniasis in felines. In a serological survey of dogs attended by the BCP from 2004 to 2012 in Londrina, Caldart et al. (2015) observed that only $1.2 \%(3 / 236)$ of the samples from animals were reactive by IFAT for Leishmania spp. In another study of dogs attended by the CCP in 2012 in the city of Telêmaco Borba, positivity was observed in $6.81 \%(13 / 191)$ of samples by IFAT (CONSTANTINO et al., 2014). These data for dogs and cats in Londrina and Telêmaco Borba led us to consider the possibility that the seroprevalence of anti-Leishmania spp. IgG antibodies in dogs and cats in those cities has increased over the years.

Regarding animal group, felines from Londrina CCP showed 6.53 times more chances of being positive for leishmaniasis than BCP felines $(\mathrm{OR}=6.53)$ and felines from Telêmaco Borba CCP showed 18.36 times more chances of being positive for leishmaniasis than BCP felines $(\mathrm{OR}=18.36)(\mathrm{p}<0.0001)$.

Regarding trypanosomiasis, recent studies have evaluated the prevalence of Chagas disease in humans in Brazil and found that the only states with no records of this disease between 2000 and 2013 were Mato Grosso do Sul, Federal District and Parana (DIAS et al., 2016). In addition, health surveillance board of Londrina (2013) published the municipal epidemiological profile data from 2010 to 2011, which indicated that during entomological surveillance for triatomine control in rural areas, no triatomines were found to be infected with Trypanosoma spp.

For T. cruzi, a greater number of seroreactive felines were revealed by IFAT $(30.8 \%)$ compared to ELISA (23.6\%), and positive animals in both tests totaled $7.6 \%$. The discrepant results between the tests were similar to those found by Alves-Martin (2013) in the state of São Paulo when evaluating felines from the protective association for animals from Ilha Solteira. The authors observed $54.9 \%(28 / 51)$ positivity in cats by IFAT and $39.2 \%$ (20/51) by ELISA. The authors suggested that this difference may be due to cross-reactions with Leishmania spp. antigens using this serological technique and that, due to the scarcity of studies using ELISA to detect T. cruzi in felines, the comparison with the results may have been inaccurate. Constantino et al. (2016) did not observe reactivity for T. cruzi for 21 dogs in the city of Curitiba. In Paraná, there are no published records of the presence of anti-Trypanosoma spp. in felines. Figure 1 show values for feline seroprevalence for T. cruzi maintained similar averages for the number of reactive animals in almost every year, except 2011 and 2012. There was no significant difference among the seroprevalence between both birth control programs (BCP, CCP).

Discussions on cross-reactivity remain controversial (ZANETTE et al., 2014) and suggest that it may occur between VL, ACL and Chagas disease (LUCIANO et al., 2009; LANGONI, 2016) because the etiological agents of these pathologies all belong to the family Trypanosomatidae and share a large number of antigens, which favors the occurrence of cross-reaction by serological methods (SOBRINHO et al., 2012). Troncarelli et al. (2009) reported that $16.5 \%(33 / 200)$ of canine serum samples showed reactivity for Leishmania spp. and T. cruzi in the city of Bauru, of which 30 were positive for Leishmania spp. by PCR; indicating the infection by Leishmania spp. and T. cruzi 
cross-reactions. According to Table 1, out of the four animals that were seroreactive for both protozoa in both IFAT and ELISA, this demonstrates possible cross-reactivity and probable infection by Leishmania spp. However, to determine whether these are cases of cross-reactivity or co-infection, complementary molecular and/or parasitological techniques are necessary to exclude one of the hypotheses (ALVES-MARTIN, 2013).

Pet animals, such as dogs and cats, have been identified as potential sentinels for many pathologies of public health importance because these animals increasingly share the same environment and even travel with owners. Thus, pet health often reflects or is suggestive of risks to human health (SCHMIDT, 2009). The results of reactive serologies for Leishmania spp. and Trypanosoma cruzi shown that these agents are present in domestic cats in the northern part of the state of Paraná. In addition, due to the higher number of seropositivity in cats from non-governmental animal protection organizations, our study suggest that owners of such locations may be more exposed to leishmaniasis when compared to other animal owners evaluated in the present study.

\section{Acknowledgements}

The authors thank the Pro-Rectory of Extension (PROEX) of the Londrina State University for the financial support to the Birth Control Project (BCP). Thanks to Profa. Dra . Sueli F. Y. Ogatta, from the Laboratory of Molecular Biology of Microorganisms, Center of Biological Sciences of UEL for yielding the T. cruzi specimens for serological tests.

\section{References}

Alves-Martin MF. Avaliação diagnóstica para Leishmania spp. e Trypanosoma cruzi em gatos domésticos procedentes da associação protetora dos animais do município de Ilha Solteira, SP, Brasil [dissertação]. Botucatu: Universidade Estadual Paulista "Julio de Mesquita Filho"; 2013.

Braga ARC, Corrêa APFL, Camossi LG, Silva RCD, Langoni H, Lucheis SB. Coinfection by Toxoplasma gondii and Leishmania spp. in domestic cats (Felis catus) in state of Mato Grosso do Sul. Rev Soc Bras Med Trop 2014; 47(6): 796-797. http://dx.doi.org/10.1590/0037-8682-00412014. PMid:25626663.

Brasil. Ministério da Saúde. Manual de vigilância e controle da leishmaniose visceral. Brasília: Editora do Ministério da Saúde; 2014.

Brasil. Ministério da Saúde. Manual de vigilância da Leishmaniose Tegumentar Americana. Brasília: Editora do Ministério da Saúde; 2017.

Caldart ET, Constantino C, Pasquali AKS, Benitez ADN, Hamada FN, Dias RCF, et al. Zoonosis in dogs and cats attended by the Birth Control Project: Toxoplasma gondii, Leishmania spp. and Leptospira spp., serodiagnosis and epidemiology. Semina: Ciênc Agrár 2015; 36(1): 253266. http://dx.doi.org/10.5433/1679-0359.2015v36n1p253.

Cardia DFF, Camossi LG, Silveira L No, Langoni H, Bresciani KDS. Prevalence of Toxoplasma gondii and Leishmania spp. infection in cats from Brazil. Vet Parasitol 2013; 197(3-4): 634-637. http://dx.doi. org/10.1016/j.vetpar.2013.07.017. PMid:23932640.

Constantino C, Pasquali AKS, Caldart ET, Ferreira FP, Marana ERM, Freire RL, et al. Seroepidemiology of Leishmania spp. in dogs residing in Telêmaco Borba, Paraná, Brazil. Semina: Ciênc Agrár 2014; 35(6): 3181-3190. http://dx.doi.org/10.5433/1679-0359.2014v35n6p3181.

Constantino C, Pellizzaro M, De Paula EFE, Vieira TSWJ, Brandão APD, Ferreira F, et al. Serosurvey for Leishmania spp., Toxoplasma gondii, Trypanosoma cruzi and Neospora caninum in neighborhood dogs in Curitiba-Paraná, Brazil. Rev Bras Parasitol Vet 2016; 25(4): 504-510. http://dx.doi.org/10.1590/s1984-29612016062. PMid:27925057.

Dias JCP, Ramos JAN, Gontijo ED, Luquetti A, Shikanai-Yasuda MA, Coura JR, et al. II Consenso brasileiro em doença de chagas, 2015. Epidemiol Serv Saude 2016; 25(spe): 7-86. PMid:27869914.

Gramiccia M. Recent advances in leishmaniosis in pet animals: epidemiology, diagnostics and anti-vectorial prophylaxis. Vet Parasitol 2011; 181(1): 2330. http://dx.doi.org/10.1016/j.vetpar.2011.04.019. PMid:21570192.

Hoffmann AR, Navarro IT, Camargo-Junior VE, Caldart ET, MitsukaBreganó R, Pereira PM. Leishmania amazonensis in dog with clinical diagnosis of visceral leishmaniasis in Paraná state, Brazil - a case report. Semina: Ciênc Agrár 2012; 33(Suppl 2): 3265-3270. http://dx.doi. org/10.5433/1679-0359.2012v33Supl2p3265.

Kirkpatrick CE, Farrell JP, Goldschmidt MH. Leishmania chagasi and L. donovani: experimental infection in domestic cats. Exp Parasitol 1984; 58(2): 125-131. http://dx.doi.org/10.1016/0014-4894(84)90027-4. PMid:6479284.

Langoni H. Leishmanioses. In: Megid J, Ribeiro MG, Paes AC. Doenças infecciosas em animais de produção e de companhia. 1st ed. Rio de Janeiro: ROCA; 2016. p. 1013-1024.

Londrina. Prefeitura Municipal. Autarquia Municipal de Saúde do Município de Londrina. Diretoria de Vigilância em Saúde. Perfil Epidemiológico 2007-2011 [online]. 2013 [cited 2018 Mar 20]. Available from: http:// www1.londrina.pr.gov.br/dados/images/stories/Storage/sec_saude/DEPIS/ perfil_epidemiologico.pdf

Luciano RM, Lucheis SB, Troncarelli MZ, Luciano DM, Langoni H. Avaliação da reatividade cruzada entre antígenos de Leishmania spp. e Trypanosoma cruzi na resposta sorológica de cães pela técnica de Imunofluorescência Indireta (RIFI). Braz J Vet Res Anim Sci 2009; 46(3): 181-187. http://dx.doi.org/10.11606/issn.1678-4456.bjvras.2009.26765.

Maia C, Campino L. Can domestic cats be considered reservoir hosts of zoonotic leishmaniasis? Trends Parasitol 2011; 27(8): 341-344. http:// dx.doi.org/10.1016/j.pt.2011.03.008. PMid:21570915.

Mancianti F. Feline leishmaniasis: what's the epidemiological role of the cat? Parassitologia 2004; 46(1-2): 203-206. PMid:15305717.

Oliveira TMFS, Furuta PI, Carvalho D, Machado RZ. A study of cross reactivity in serum samples from dogs positive for Leishmania sp., Babesia canis and Ehrlichia canis in enzyme-linked immunosorbent assay and indirect fluorescent antibody test. Rev Bras Parasitol Vet 2008; 17(1): 7-11. http://dx.doi.org/10.1590/S1984-29612008000100002. PMid:18554433.

$\mathrm{R}$ Core Team. A language and environment for statistical computing [online]. R Foundation for Statistical Computing; 2016 [cited 2017 Jan 4]. Available from: https://www.R-project.org/

Savani ESMM, Camargo MCGO, Carvalho MR, Zampieri RA, Santos MG, D'Áuria SRN, et al. The first record in the Americas of an autochthonous case of Leishmania (Leishmania) infantum chagasi in a domestic cat (Felis catus) from Cotia County, São Paulo state, Brazil. Vet Parasitol 2004; 120(3): 229-233. http://dx.doi.org/10.1016/j. vetpar.2004.01.008. PMid:15041097. 
Schmidt PL. Companion animals as sentinels for public health. Vet Clin North Am Small Anim Pract 2009; 39(2): 241-250. http://dx.doi. org/10.1016/j.cvsm.2008.10.010. PMid:19185191.

Schoonjans F, Zalata A, Depuydt CE, Comhaire FH. MedCalc: a new computer program for medical statistics. Comput Methods Programs Biomed 1995; 48(3): 257-262. http://dx.doi.org/10.1016/0169-2607(95)017038. PMid:8925653.

Schubach TMP, Figueiredo FB, Pereira SA, Madeira MF, Santos IB, Andrade MV, et al. American cutaneous leishmaniasis in two cats from Rio de Janeiro, Brazil: first report of natural infection with Leishmania (Viannia) braziliensis. Trans R Soc Trop Med Hyg 2004; 98(3): 165-167. http://dx.doi.org/10.1016/S0035-9203(03)00040-3. PMid:15024926.

Silva AV, Sousa CCD, Pita PD, Brazil RP, Carreira JC. The first record of american visceral leishmaniasis in domestic cats from Rio de Janeiro, Brazil. Acta Trop 2008; 105(1): 92-94. http://dx.doi.org/10.1016/j. actatropica.2007.09.001. PMid:17953938.

Silveira L No, Marcondes M, Bilsland E, Matos LVS, Viol MA, Bresciani KDS. Clinical and epidemiological aspects of feline leishmaniasis in Brazil. Semina: Ciênc Agrár 2015; 36(3): 1467-1480. http://dx.doi. org/10.5433/1679-0359.2015v36n3p1467.

Silveira TGV, Arraes SMAA, Bertolini DA, Teodoro U, Lonardoni MVC, Roberto ACBS, et al. Observaçôes sobre o diagnóstico laboratorial e a epidemiologia da leishmaniose tegumentar no Estado do Paraná, Sul do Brasil. Rev Soc Bras Med Trop 1999; 32(4): 413-423. http://dx.doi. org/10.1590/S0037-86821999000400013. PMid:10495672.

Silveira TGV, Teodoro U, Arraes SMAA, Lonardoni MVC, Dias ML, Shaw JJ, et al. An autochthonous case of cutaneous leishmaniasis caused by Leishmania (Leishmania) amazonensis Lainson \& Shaw, 1972 from the north of Paraná State, Brazil. Mem Inst Oswaldo Cruz 1990; 85(4): 475-476. http://dx.doi.org/10.1590/S0074-02761990000400014. PMid:2152201.

Sobrinho LSV, Rossi CN, Vides JP, Braga ET, Gomes AMD, Lima VMF, et al. Coinfection of Leishmania chagasi with Toxoplasma gondii, Feline Immunodeficiency Virus (FIV) and Feline Leukemia Virus (FeLV) in cats from an endemic area zoonotic visceral leishmaniasis. Vet Parasitol 2012; 187(1-2): 302-306. http://dx.doi.org/10.1016/j.vetpar.2012.01.010. PMid:22285010.
Souza AI, Barros EM, Ishikawa E, Ilha IM, Marin GR, Nunes VL. Feline leishmaniasis due to Leishmania (Leishmania) amazonensis in Mato Grosso do Sul state, Brazil. Vet Parasitol 2005; 128(1-2): 41-45. http://dx.doi. org/10.1016/j.vetpar.2004.11.020. PMid:15725531.

Szargiki R, Castro EAD, Luz E, Kowalthuk W, Machado AM, ThomazSoccol V. Comparison of serological and parasitological methods for cutaneous leishmaniasis diagnosis in the state of Paraná, Brazil. Braz J Infect Dis 2009; 13(1): 47-52. http://dx.doi.org/10.1590/S141386702009000100011. PMid:19578630.

Thomaz-Soccol V, Castro EA, Schühli SG, Carvalho Y, Marques E, Pereira EF, et al. A new focus of cutaneous leishmaniasis in the central area of Paraná state, southern Brazil. Acta Trop 2009; 111(3): 308-315. http://dx.doi.org/10.1016/j.actatropica.2009.05.013. PMid:19482000.

Troncarelli MZ, Camargo JB, Machado JG, Lucheis SB, Langoni H. Leishmania spp. and/or Trypanosoma cruzi diagnosis in dogs from endemic and nonendemic areas for canine visceral leishmaniasis. Vet Parasitol 2009; 164(2-4): 118-123. http://dx.doi.org/10.1016/j.vetpar.2009.06.027. PMid:19625128.

Vides JP, Schwardt TF, Sobrinho LSV, Marinho M, Laurenti MD, Biondo AW, et al. Leishmania chagasi infection in cats with dermatologic lesions from an endemic area of visceral leishmaniosis in Brazil. Vet Parasitol 2011; 178(1-2): 22-28. http://dx.doi.org/10.1016/j.vetpar.2010.12.042. PMid:21282011.

World Health Organization - WHO. Sustaining the drive to overcome the global impact of neglected tropical diseases: second WHO report in neglected tropical diseases [online]. 2013 [cited 2017 Jan 6]. Available from: http:// www.who.int/neglected_diseases/9789241564540/en/

World Health Organization - WHO. Chagas disease in Latin America: an epidemiological update based on 2010 estimates. Wkly Epidemiol Rec 2015; 90(6): 33-43. PMid:25671846.

Zanette MF, Lima VMFD, Laurenti MD, Rossi CN, Vides JP, Vieira RFDC, et al. Serological cross-reactivity of Trypanosoma cruzi, Ehrlichia canis, Toxoplasma gondii, Neospora caninum and Babesia canis to Leishmania infantum chagasi tests in dogs. Rev Soc Bras Med Trop 2014; 47(1): 105 107. http://dx.doi.org/10.1590/0037-8682-1723-2013. PMid:24603745. 